\title{
PerCuRsos de ANÁLISE do VeSTUÁRIo EM FILMES PORTUGUESES DE ETNOFICÇÃO
}

\author{
Caterina Cucinotta
}

\begin{abstract}
Resumo
O presente artigo versa sobre o tema do documentário e da ficção no cinema de etnoficção português, focalizando-se no estudo do vestuário como fenómeno, ora votado a explicitar a verosimilhança das sequências, ora usado enquanto ferramenta para criar uma simulação da realidade. Tratamos o termo etnoficção como se fosse um género cinematográfico e escolhemos, como exemplo de análise três trilogias do cinema português. Entendemos o vestuário de acordo com os novos conceitos do corpo revestido que vêm da Fashion Theory. Analisar o vestuário de filmes por género ajuda, por um lado, na criação de uma primeira definição de todo este tipo de vestuário e, por outro, a compreender a sua importância dentro de uma obra fílmica. O enquadramento teórico sobre Fashion Theory e sobre o conceito de etnoficção será aplicado aos filmes escolhidos, tentando-se ampliar os referidos conhecimentos através da introdução de outros autores que se debruçaram sobre os dois assuntos, a fim de unificar os dois conceitos, do corpo revestido e da etnoficção, num só, o conceito de vestuário cinematográfico.
\end{abstract}

\section{Palavras-chave}

Cinema português; etnoficção; vestuário cinematográfico

\begin{abstract}
This article explores the theme of documentary and fiction in the ethnofiction Portuguese cinema, with the costumes in the middle of this binomial as a phenomenon that explains it as a likelihood of the sequences and as a tool to create a simulation of the reality. We treat the term ethnofiction as it would be a cinematographic genre and we choose, as an example to analyse, 3 Trilogies from the Portuguese cinema. Also we treat the costumes according to the new concept about the clothed body that come from Fashion Theory. To analyse films costumes by the genre helps to create of a first definition of this kind of clothing and to understand its importance inside a filmic action. The theoretical parts about Fashion Theory and about the ethnofiction concept will be applied to the chosen films, trying to extend the knowledge through the introduction of others authors who also work about the two themes, to unify them, the clothed body and the ethnofiction, in the one of cinematographic costumes.
\end{abstract}

\section{Keywords}

Ethnofiction; film costumes; portuguese cinema 


\section{INTRODUÇÃO}

Com este ensaio procuraremos apresentar uma análise do vestuário em filmes portugueses dividindo-os em três trilogias e dirigindo a nossa atenção para a interseção entre moda e cinema, numa perspetiva comparatista.

Este estudo' pode ser definido como um esboço preliminar para um discurso sobre vestuário cinematográfico, tendo por objetivo específico a aplicação da Fashion Theory a um género cinematográfico. Ao optar por este caminho, tencionamos explicar o desenho de uma metodologia que implemente discursos análogos e que também sirva como ponto de partida para outros investigadores da imagem em movimento que estejam interessados no corpo, no seu revestimento e nas implicações deste dentro do enquadramento no plano de um filme.

A Fashion Theory, mais do que um estudo sobre a moda, pressupõe a compreensão dos modos e dos gestos cristalizados em vestuário. Trata-se, no fundo, de enunciados não ditos que, revestindo o corpo que o veste, prolongam, desdobram ou suspendem os gestos das personagens. Tal será particularmente revelador quando falamos em etnoficção, um género cinematográfico que mistura dentro de si documentário e ficção.

A Fashion Theory servirá como base teórica e ponto de partida numa metodologia que cruza o vestuário com os Estudos Fílmicos e escolhemos a etnoficção como objeto de estudo, destacando alguns filmes portugueses constituídos em Trilogias.

A primeira trilogia é a Trilogia do Mar, de Leitão de Barros, que compreende: Nazaré, Praia de Pescadores e Porto de Turismo (1927), Maria do Mar (1929) e Ala arriba! (1942).

A segunda é a Trilogia de Trás-os-Montes, de António Reis e Margarida Cordeiro, que compreende: Trás-os-Montes (1976), Ana (1982) e Rosa de Areia (1989).

A terceira e última é a Trilogia das Fontainhas, de Pedro Costa, e compreende: Ossos (1997), No Quarto da Vanda (2000) e Juventude em Marcha (2006).

\section{FormulaÇÃo Do PROBLEMA}

No início do terceiro capítulo do livro Changing Places: Costume and Identity, da investigadora inglesa Pam Cook, a autora escreve:

o design de vestuário é uma das áreas menos investigadas da história do cinema. Há uma vasta gama de literatura acerca do vestuário teatral e, desde os anos 70, existe um interesse crescente em moda no círculo dos historiadores de Cultura; mas, na sua maioria, os Estudos Fílmicos passaram ao lado desta tendência. (...) a falta de interesse no vestuário passa a ser particularmente significativa se considerarmos o quão importante a roupa é para a narrativa, na criação de personagens, no fortalecimento do enredo, na sugestão de ambientes, etc. (Cook, 1996, p. 41)

\footnotetext{
' Este artigo é resultado de uma reelaboração da investigação em doutoramento com o titulo O vestuário no cinema: percursos de analise em filmes portugueses de etnoficção. Para mais informação, aceder a https://run.unl.pt/handle/10362/16297
} 
Este texto foi publicado originalmente em 1996 e, até à data, ocorreram pouquíssimas alterações em relação ao assunto. Porém, hoje em dia, se algo mudou é apenas porque provavelmente se começou a considerar o vestuário como um elemento importante para a compreensão de uma obra fílmica. No entanto, passados todos estes anos, aquele que é o ponto de partida desta investigação, tal como referido por Cook (1996), permanece inalterado.

Além da sua função geral na compreensão visual das imagens em movimento, o vestuário ajuda na construção de percursos paralelos ao enredo central. Fornece informações sobre personagens e sobre o contexto histórico e social em que estas atuam. Comunica verosimilhança e é capaz de estabelecer uma espécie de pacto entre o filme e o espetador que é, assim, levado a acreditar que o que vê no ecrã é a realidade. Logo, um dos primeiros problemas é o facto de o vestuário cinematográfico nunca ter usufruído de uma análise detalhada e paralela dentro dos próprios estudos fílmicos.

De acordo com a pesquisa efetuada, os primeiros estudos sobre vestuário cinematográfico acessíveis online e em bibliotecas especializadas remontam à primeira metade do século passado e representam um discreto ponto de partida no percurso a efetuar pelo universo fílmico da roupa. Se em França e Itália, a partir dos anos quarenta, foram muitos os figurinistas que escreveram breves textos ou ensaios sobre o seu próprio trabalho (Annenkov, 1955; Sensani \& Lara citados em Verdone, 1986) e a mesma coisa acontecera com figurinistas de Hollywood (Adrian citado em Watts, 1939; Banton, 1935), para um trabalho cuidado e pormenorizado que se afastasse um pouco da perspetiva da moda e se introduzisse no mundo efetivo do cinema, teve de esperar-se até 1950, ano em que Mário Verdone, professor de Filmologia em Roma, editou o livro Scena e Costume nel Cinema². O texto aprofunda alguns aspetos históricos, mas também culturais, da cenografia e do vestuário cinematográficos, tendo como ponto de partida o cinema e não a moda, no caso do vestuário, e o cinema, e não a arquitetura, no caso da cenografia. Esta aparenta ser uma obra mais completa do que as anteriores, pois tenta colocar de parte as meras curiosidades "do fabuloso mundo do cinema, feito de glamour e divas, para se concentrar na elaboração de um esboço de pesquisa do elemento fílmico no próprio vestuário" (Verdone, 1986, p. 40). Continua o autor:

a questão não é vestir as pessoas com o que lhes fica melhor, mas sim vestir as imagens, criar alguém, participar na elaboração de um fantasma. Assim, surgem necessidades que quase nada têm a ver - pelo menos diretamente - com a moda, com os grandes criadores, a mania de Paris, a história da arte, o folclore, o artesanato. (Verdone, 1986, p. 40)

O conceito de vestir as imagens, proposto por Verdone, é de particular interesse e, peculiarmente, possui uma estreita ligação com o conceito inovador de Surface materiality in film de Giuliana Bruno (2014).

O maior obstáculo neste tipo de investigação é a pouca importância que os estudos fílmicos deram ao vestuário como elemento dramático na comunicação de um

\footnotetext{
${ }^{2}$ Texto consultado na sua edição de 1986.
} 
filme. O vestuário cinematográfico não ganhou uma posição predominante nos estudos académicos porque sempre se pensou, erroneamente, que se tratasse de um elemento puramente decorativo. Os cruzamentos entre estudos culturais e estudos semióticos afirmam exatamente o contrário: o vestuário dentro de um filme, qualquer que seja o género, transmite sempre alguma sensação em relação ao filme e ao realizador que o pensou (Bruno, 2014). Além disso, se por um lado o vestuário de um filme de ficção é o resultado de cuidadosas reconstruções baseadas em estereótipos culturais, o vestuário de uma etnoficção expõe aspetos peculiares e incomuns, por outro.

Em geral, o fio condutor desta investigação centra-se no uso que o cinema faz do vestuário enquanto veículo para traçar eixos paralelos à narrativa principal. Ou seja, a importância menor que os estudos fílmicos deram ao vestuário torna-se o ponto de partida deste estudo. Propõe-se, assim, como problemática principal, uma tentativa de aplicar uma teoria, originária nos estudos sobre moda e traje, que tem o nome de Fashion Theory, a um género cinematográfico.

\section{A FASHION THEORY COMO TEORIA DE BASE}

O termo Fashion Theory refere-se a um âmbito interdisciplinar que contempla a moda como um sistema de significados em que se produzem as representações culturais e estéticas do corpo revestido. Ao longo do nosso percurso de pesquisa, analisámos a moda como uma construtora de significados e figuras do imaginário, ou mitos, que se reproduzem na esfera social, tornando-as naturais e eternas. Os meios de comunicação, em primeiro lugar o cinema, são um grande depósito e motor do imaginário social e agem em estreita sinergia com a moda.

Vários são os eixos que definem/integram a Fashion Theory. Nomeadamente, no que diz respeito ao traje ou ao vestuário: antropologia, sociologia, filosofia, psicologia, semiótica e estudos culturais. A partir de um artigo de Patrizia Calefato (2002), que tem por título Fashion Theory, foi feita uma tentativa de organizar cronologicamente os pontos fundamentais da altura em que a teoria começou a ganhar vida, até se desenvolver no conceito que é hoje. Desde o ensaio de Georg Simmel de 1895 sobre a moda (Simmel, 1996) até aos escritos de Roland Barthes, tentar-se-á ilustrar as teorias que colocaram, quer a moda, quer o traje, no centro da investigação, tentando não cair em análises puramente textuais ou históricas.

A seu modo, Simmel foi um precursor, pois inseriu a moda dentro do binómio indivíduo/sociedade. A partir desse binómio nasceram outros, como, por exemplo, homem/ mulher, ricos/pobres, imitação/diferenciação - binómios com que, primeiro Simmel e mais tarde, em 1897, Veblen (1969), foram deduzindo o quanto a moda, antes de ser entendida em termos gerais, precisava de ser enquadrada na sociedade a fim de melhor se compreender a sua função. Seguindo o percurso cronológico indicado por Calefato (2002), torna-se necessário passar pelo Estruturalismo para melhor perceber a distinção entre moda e traje. Foi Saussure (2009), em 1967, quem aproximou a moda à linguagem e, a partir daí, outros semióticos e historiadores da cultura passaram a interessar-se pelo 
vestuário. A seguir, será a vez de Petr Bogatyrëv (1937/1986) que, em 1937, publicou um ensaio sobre trajes folclóricos onde aplica o método funcionalista ao vestuário, individualizando no seu interior um escalão de cinco funções principais.

No caso de Bogatyrëv, o que torna a sua análise interessante é a construção segundo um sistema funcionalista, que individualiza o traje folclórico numa hierarquia de funções. Durante o estudo, ao colocar em contraposição a moda e o traje, o autor encontra fortes contrastes entre os dois fenómenos: enquanto o primeiro adquire um sentido apenas em função da mudança e da rutura com o passado, o segundo vive de continuidade e tradição. A forma de vestir do traje popular, tão estável e previsível, é a que mais capta a atenção de Bogatyrëv (1937/1986, pp. 93-94) que, em 1937, chegará à definição das cinco funções do traje: a estética, a erótica, a prática, a mágica e a regional.

Se com Roland Barthes (1957-1963/2009) se afinaram os conhecimentos sobre a moda como discurso social, introduzindo o conceito de corpo vestido, do qual derivam outros conceitos (corpo espetáculo, corpo jovem...), chega-se finalmente ao conceito contemporâneo que dele advém e que será desenvolvido no trabalho de outra linguista, Patrizia Calefato. Desde finais dos anos 80 que a investigadora e professora italiana tem vindo a desenvolver a teoria do corpo revestido ligada aos estudos sobre Fashion Theory, no âmbito da chamada mass-moda e da performance do corpo: "no cinema, mais do que no teatro e na fotografia, o corpo revestido é o sujeito fundamental, a ação resume-se toda aí, para além da escolha do vestuário de cena, precisamente no processo de representação do corpo" (Calefato, 1986, p. 14).

Trata-se de um discurso diferente sobre o corpo que tenta excluir os extremos, "pronunciando o corpo" através das suas máscaras. Pode tentar-se "pronunciar o corpo" nas suas aberturas infinitas com outros corpos e com o mundo, dando-lhe "uma valência relativa à cultura dentro da qual estas imagens se situam" (Calefato, 1986, p. 8). Em meados dos anos 70, certas investigações feministas focam a sua atenção na construção cinematográfica do corpo feminino como objeto inteiramente preso dentro de uma visão patriarcal das relações humanas e do poder. A este propósito, Laura Mulvey, num ensaio de 1974 (traduzido para italiano em 1978), separa o homem da mulher no dispositivo cinematográfico, definindo o primeiro como olho que olha e a segunda como o espetáculo a ser olhado ou, mais especificamente, como a performance a olhar. Segundo Patrizia Calefato, graças a estas pesquisas pioneiras, pôde constituir-se uma base teórica sobre a qual, durante os anos 80 do século passado, se foi implantando uma análise da corporeidade cinematográfica que começava também a abranger a roupa de cena, decisiva na construção do masculino e do feminino. Por isso, o corpo revestido é o território físico-cultural onde se realiza a performance visível e sensível da nossa identidade exterior.

\section{A ETNOFICÇÃo PORTUGUESA COMO OBJETO DE ESTUdo}

A etnoficção portuguesa, cruzamento entre o documentário e a ficção, foi escoIhida enquanto geradora de uma importante interseção também ao nível do vestuário. 
Pondo-se o vestuário exatamente entre o real e o fictício, resulta, agora, um símbolo de verdade na história contada, uma reconstrução do conceito de comunidade.

Ao reunir as pesquisas feitas ao longo destes anos e, na tentativa de unificar numa só definição de género cinematográfico as três trilogias analisadas, começou por esclarecer-se algumas dúvidas em relação ao material investigado. Por um lado, é um dado adquirido que websites como a Wikipedia.com não podem ser citados como fonte única e solução para questões, já que a busca de respostas no vasto universo da internet pode dar forma a outras questões que, ao desviarem-se da discussão central, podem gerar confusão na busca de uma resolução. Porém, por outro lado, em relação à especificidade do conceito de etnoficção e a sua definição do ponto de vista cinematográfico, a realidade é que as primeiras respostas foram encontradas na internet. Pensa-se, de facto, que, no momento em que se decide trabalhar com um género cinematográfico que possui referências sólidas tão limitadas, um dos poucos percursos viáveis é reunir o máximo de informação possível para depois conjugar peças na fragmentação conceitual que cada filme pode propor sobre o assunto.

Considerando que o conceito de etnoficção tem a sua origem na disciplina da antropologia visual ${ }^{3}$, há ainda a acrescentar que só há poucos anos este começou a ser utilizado no âmbito cinematográfico, tendo sido reconhecido como género. Uma das primeiras interessantes definições propostas afirma que a etnoficção ${ }^{4}$ é o género cinematográfico que tem como objeto de estudo um grupo de pessoas que formam uma comunidade. Partindo daqui, de uma forma geral, na análise dos conteúdos o objeto de estudo pode ser individualizado no homem que, vivendo numa comunidade, aceita/ adota certas regras e abandona outras. Para possuir as características que o definam como obra de etnoficção, um filme deve focar a sua atenção sobre dois eixos principais: por um lado, os comportamentos individuais que põem em destaque a personalidade subjetiva e, por outro, o ímpeto por parte da comunidade para que tal não desestabilize os equilíbrios interiores desta. Apesar do objeto filmado ser importante, o elemento que mais contribui para transformar um filme etnográfico numa etnoficção é a metodologia com que se aborda a própria filmagem, isto é, além dos conteúdos, também as formas são fundamentais. De facto, é difícil considerar que um filme consiga equilibrar-se numa sintonia completa entre as formas do documentário e da ficção sem nunca se desequilibrar, ora de um lado, usando o próprio documentário como metodologia, ora do outro, forçando a mão com a ficção, usada paradoxalmente como espelho da realidade. Porém, a parte porventura mais interessante desta nova conceitualização está no deslize em que o documentário se mascara de ficção e a ficção mascara-se de documentário para fingir que é ficção, e vice-versa.

Ou seja, o debate acerca da etnoficção tem gerado muito interesse no âmbito cinematográfico porque o que definimos de etnoficção, outros chamaram de filme-ensaio (Rascaroli, 2009) ou cinema indisciplinar (Overhoff Ferreira, 2013) e atribuir definições a

3 Desde 1992, existe em Portugal o NAV, Núcleo de Antropologia Visual. Retirado de http://ceas.iscte.pt/gr_avisual.php 4 Retirado de http://pt.wikipedia.org/wiki/Etnoficção 
um objeto que não quer ser definido, não está aqui em causa. O que vai aqui emergindo para debate é o questionar como as imagens em movimento criam ligações com outras linguagens, outros mundos, outras artes; como, através destas ligações, os realizadores tornam-se artistas também a outros níveis; e como a ligação entre as artes e o cinema gera conceitos paralelos ao enredo do filme.

\section{OS TRÊS NÍVEIS DE ANÁLISE}

Para atingir o objetivo da criação de ligações entre linguagens diferentes como o são a moda e o cinema, procurámos uma metodologia útil, a fim de analisar peças de vestuário presentes nas sequências dos filmes escolhidos. Porém, trata-se de uma metodologia utilizável também ao nível da abordagem de outras linguagens, diferentes da moda e do vestuário, presentes num dos filmes.

Estamos a referir-nos à análise segundo três níveis: o nível cinematográfico, o nível extracinematográfico e o nível fílmico (Calefato \& Giannone, 2007).

Enquanto os dois primeiros analisam as informações das diferentes características sociais, psicológicas e culturais do indivíduo ou ator que veste uma peça de roupa, o último resultou ser o mais apropriado para o propósito da investigação. A análise das peças de vestuário pretendeu ser mais fílmica, observando as mesmas do ponto de vista da câmara e não só do indivíduo que as veste pois o vestuário é um dos elementos que o realizador tem para se aproximar, ora da verdade, ora da ficção.

Em linhas gerais, o nível cinematográfico representa a relação entre o uso real das peças de vestuário e o uso do vestuário pensado para a ficção bidimensional do ecrã: há peças que funcionam na vida real, mas que não se ajustam bem às regras e estética do ecrã, onde tudo fica diferente, desde as cores até à textura. O nível extracinematográfico representa talvez o oposto, porque o vestuário cinematográfico também transmite ao espetador uma reelaboração da realidade através de estereótipos e identidades visuais que ele próprio cria. De certa forma, as imagens cinematográficas trazem para o mundo real modelos reproduzíveis, muito em parte devido às peças de vestuário.

Por fim, o nível filmico é o mais complexo e é onde o vestuário ganha importância, porque faz parte da estreita ligação entre ator e personagem: o que o ator quer transmitir ao espetador tem um início exterior no seu revestimento. $O$ vestuário pode, neste sentido, representar uma voz fundamental do contrato de veridicção de Greimas (1985) que cada filme estipula com o seu espetador, o qual decide conscientemente acreditar no que as imagens fictícias lhe mostram com base numa coerência estabelecida por contrato. Greimas escreve:

o discurso é o lugar frágil onde estão inscritas e são lidas a verdade e a falsidade, a mentira e o segredo; (...) equilíbrio mais ou menos estável que vem de um acordo implícito entre os dois actantes da estrutura da comunicação. Este tácito compromisso é chamado de contrato fiduciário". (Greimas, 1985, p. 45) 
O nível fílmico é também importante, pois, na maioria dos casos, é criador de linhas narrativas paralelas e invisíveis ao enredo principal.

Considerando que um fundamento essencial na construção de figuras cinematográficas é uma harmoniosa adequação do vestuário, pode entender-se o quão este elemento tem sido subvalorizado. Trata-se de um elemento-chave na leitura da fruição cinematográfica, porque, ao nível inconsciente, o que é simplesmente designado roupa consegue operar uma síntese entre as características interiores da personagem e as características físicas dificilmente transformáveis do ator que se encontra a interpretar. O lado performativo do vestuário cinematográfico é assim clarificado: se o espetador consegue acreditar que um ator conhecido através de outros média, com uma existência para além do filme imediato, também pode ser aquela personagem, parte integrante de um mundo paralelo, o do filme, do qual passa a fazer parte, então, isto acontece também graças ao seu vestuário, na medida em que contribui para permitir uma passagem da vida real à ficção, tornando a ficção credível.

É através do contrato de veridicção que são expressas as regras que servem de estrutura ao mundo possível criado no ecrã cinematográfico. Se, por um lado, o espectador suspende a sua incredulidade em relação às sequências filmadas, é também porque o realizador, por seu turno, se preocupa em deixar bem claro em que tipo de ambiente se desenrola a narração, tentando conjugar ator, lugar, tempo e acontecimento. Trata-se de uma espécie de passagem de testemunho entre o realizador e o espetador que culmina na escolha de um vestuário apropriado e que também faz com que o género cinematográfico escolhido não seja casual. Na etnoficção, no documentário em geral e no documentário etnográfico em específico, o contrato de veridicção surge com uma espontaneidade bastante maior, pois trata-se não de um vestuário do dia a dia, mas de trajes populares saturados de significados próprios. Juntando ao traje popular os elementos relacionados com o lugar, torna-se evidente uma vontade por parte do realizador de que o espectador acredite que o que está a ver é, de facto, real, verdadeiro, existente.

\section{A ANÁlise dA TriLOGIA do MAR}

Ao analisar a Trilogia do Mar de Leitão de Barros, pode ficar-se surpreendido com a quantidade de citações ao nível de vestuário que surgem ao longo dos três filmes: desde a importância do traje feminino cuja função é cobrir as formas do corpo e o rosto, passando por ligações inesperadas entre a câmara, o corpo e a narrativa do filme.

É de sublinhar a forma inovadora como Leitão de Barros aborda os conceitos em relação ao revestimento do corpo. Por detrás do género documentário, usado como dispositivo, este concebe uma série de ficções para (re)percorrer aqueles que são, na sua opinião, os costumes do povo nazareno, introduzindo ao mesmo tempo o seu cunho pessoal. A câmara muda de posição e de atitude consoante se encontra diante da comunidade ou em frente de uma singular personagem.

Reflitamos um pouco sobre a importância dada à nudez de Maria do Mar no momento em que é salva por um rapaz de uma família inimiga, a importância de assinalar este gesto de união na presença de dois corpos nus, em substituição de trajes-símbolos 
de divisões familiares. No início da sequência vêem-se dois grupos diferentes de banhistas, homens e mulheres, cada um com um vestuário próprio identificando a sua diversidade: no momento em que a câmara mostra em detalhe um seio de mulher, parecem cair as regras da comunidade. Apagam-se as diferenças sociais no momento em que a câmara parece não querer exibir apenas o proibido mas, de facto, despir Maria do Mar da sua identidade.

Fica claro o intuito de enganar ou, pelo menos, de confundir o espetador, mostrando o gesto como uma casualidade, conferindo-lhe ainda mais força. Se tivesse acontecido casualmente, teria talvez sido eliminado durante a montagem. A intenção do realizador reside na sua vontade de mostrar uma mulher despida da sua roupa, assim como da sua identidade.

Em Ala Arriba! de 1943, logo no início do filme, o espetador toma conhecimento do quão importantes são as camisolas com as marcas sociais na comunidade da Póvoa de Varzim, feita de sardinheiros e lanchões.

O filme foi rodado nos anos 40 do século passado, quando a principal diferença entre os ricos e os pobres, a nível de vestuário, era basicamente o interesse, ou falta dele, em acompanhar as novas tendências: nas cidades, as pessoas com dinheiro vestiam-se segundo os ditames da moda, enquanto as pessoas do povo vestiam-se para se cobrir, enquanto o fenómeno que acontece dentro da comunidade fechada da Póvoa de Varzim possui algo que pode ser associado à moda. Apesar de se falar em traje popular, as marcas patentes nas camisolas, diferentes segundo a classe social, fazem lembrar o quanto é importante, ainda hoje, vestir uma peça que tenha estampadas/impressas marcas que indiquem a que mundo se pertence.

Allison Lurie afirma que, ao longo da história, "o vestuário mostrou a posição social de quem o vestia. Assim como as linguagens mais antigas estão repletas de títulos elaborados e de formas de invocação, durante milhares de anos certas modas indicaram patentes elevadas ou reais" (2007, p. 57). Quando Bogatyrëv descreve a função de classe no traje do dia-a-dia explica:

a tendência em distinguir as várias classes através do vestuário também se conserva quando as peças ficam niveladas, ou seja, na passagem de vestuário rural, local, a vestuário de cidade, internacional. A tendência das várias classes de fazer sobressair as próprias recíprocas diferenças fica como a única forma que, ao longo dos vários períodos, se enche de conteúdos diferentes. (Bogatyrëv, 1986, p. 98)

Considerando o fenómeno em si, consegue distinguir-se, de facto, no traje popular, uma certa tendência, ou moda, para criar uma divisão visual entre ricos e pobres. Em geral, o reconhecimento de um indivíduo como membro de um grupo através da roupa é prática habitual; mas, o que se revela interessante no filme, é a forma provisória como tal se manifesta visualmente: através da roupa. Nada é definitivo, como também não o é vestir uma camisola com marcas diferentes, graças a um casamento: um ato de amor que pode mudar o percurso social de uma pessoa. 


\section{A ANÁLISE dA Trilogia de Trás-os-Montes}

Continuando com a segunda trilogia, o significado e o uso do vestuário foi integrando sempre a ideia específica que o realizador queria mostrar acerca da comunidade: António Reis e Margarida Cordeiro na Trilogia de Trás-os-Montes mostram, por exemplo, como na mistura entre ficção e documentário, entre imaginação, recordações e lugares que existem, há uma ligação direta que também pode ser mostrada através do vestuário.

Os investigadores que se interessam pela obra da dupla Reis/Cordeiro fazem literalmente (e na prática) um esforço muito grande para ir ao encontro da curiosidade de ver as películas da Trilogia de Trás-os-Montes. O ritual do espetador em relação à visibilidade do filme faz parte de um mecanismo que também inclui o vestuário, ele próprio portador de significados mágicos que, aliando-se à aura criada em torno dos filmes, formam a chamada "estética da invisibilidade no cinema de Reis e Cordeiro" (Torres, 1991-1992, p. 124). Apesar de poder parecer um assunto bizarro no caso desta trilogia tão obscura, é também importante analisar os objetos que fazem parte dos enquadramentos, objetos que podem parecer simples decorações, mas que contam histórias paralelas em relação à narração e às próprias personagens.

No caso de Trás-os-Montes, acontece algo que pode apelidar-se de mágico: o rapaz que acabou de sonhar com uma memória que pertence à sua mãe, acorda e sai da cama de robe. Aparentemente, a cama, a casa, os móveis e o próprio robe de dormir são sempre os mesmos, pelo menos o jovem não estranha nada, e, despindo-se da roupa de cama, começa a vestir uma camisa com botões. A câmara observa este seu ato de se despir com muita atenção, através de pouquíssimos movimentos, só para o acompanhar da cama até ao lavatório. Quando o rapaz acaba de se vestir, coloca um gorro com laivos vermelhos, assentando-o bem na cabeça, em frente ao espelho.

Eis que acontece o facto extraordinário: na sequência seguinte, ao ver o rapaz a passear pelo campo com um amigo, compreende-se finalmente que aquele despir da roupa de dormir não era somente o que parecia, mas sim um fato mágico com que se consegue baralhar o tempo - o jovem despiu a sua identidade para regressar no tempo, tendo, para tal, que vestir outro fato, outro eu, e a insistência com que ele assentou o gorro na cabeça é o primeiro sinal desta mudança, uma espécie de ajuste. A nudez do rapaz refletida no espelho, no momento da passagem do tempo, parece dizer que "o corpo é uma contínua contestação do privilégio atribuído à consciência, de dar um significado a cada coisa. Ele vive, pois é esta contestação (Levinas, 1971, p. 130). Os dois amigos, vestidos de pajens medievais, vagueiam pelos campos num grande passeio. E, finalmente, ao chegar à aldeia de Montesinho, outro Montesinho, longe do tempo de Luís e Armando, um dos dois rapazes questiona: "mas como é que dois rapazes como nós podem ser os nossos antepassados? (...) Talvez o nosso passeio não tenha demorado umas poucas horas, mas sim muitos anos, algumas centenas de anos"5. Os rostos dos dois amigos, os próprios corpos e o acontecimento em si podem ser reconhecidos no que Luis Marin (1971) chama o "neutro plurale", ou seja, aquele lugar utópico que ocupa

5 Minuto 47:36 do filme Trás-os-Montes 
a distância, o que resta entre a marca e a não marca, entre a verdade e a ficção, entre o possível e o impossível, onde a diferença não se anula na síntese como também não está sujeita às categorias universais da razão, mas é mantida, imobilizada e perpetuada sob a forma de uma polémica infinita. O traje é, portanto, o traço oficial da sua linguagem, do seu tempo produtivo, tempo da afirmação do indivíduo como sujeito do mundo. O traje, que em latim é habitus, partindo desta sua denominação original, tenta fixar a identidade evanescente de um corpo em trânsito que se encontra entre dois tempos diferentes e do qual a irredutibilidade está expressa nas linhas do rosto, que representam o traçado de uma comunidade firme. Porém, ao mesmo tempo, o habitus joga com a sua função identificadora, ao definir uma espécie de status através dos detalhes e dos acessórios, neste caso o gorro, no momento em que tornam a personagem "um tipo" e a colocam num espaço/tempo bem definidos. E os detalhes falam também do efémero, da contínua mudança que o próprio habitus traz ao corpo, nas palavras de Onorati (2000, pp. 107-115), o seu ser "escritura do corpo" que constrói e desconstrói a relação de sentido entre indivíduo e comunidade. Por isso, o traje de época medieval, ao falar do rapaz, fala também um pouco sobre si, do seu ser um signo.

\section{A anÁlise da Trilogia das Fontainhas}

Ao estudar a Trilogia das Fontainhas de Pedro Costa, apresentou-se finalmente uma sensação de amalgamento ou coerência visual: a componente visual do filme resulta ligada ao vestuário como fio condutor dos conceitos que vão ser explicados ao longo do filme, uma espécie de enredo paralelo que serve de suporte ao filme, mas que consegue criar no espetador uma consciência sobre os factos narrados.

Quase se começa a pensar que a própria Vanda, do filme No Quarto da Vanda, é o corpo revestido, ou seja, já não se está a falar de Vanda e da teoria do corpo revestido mas da Vanda como pico de união, como expoente claro, visível do que é hoje o corpo revestido no cinema e de quão importante esta questão é para que um filme seja bem sucedido.

Pedro Costa conseguiu criar uma linha narrativa paralela, que passa dos corpos revestidos até às casas que se encontram a ser demolidas no Bairro das Fontainhas.

Enquanto o bairro está a ser demolido pela Câmara Municipal de Lisboa, o vestuário continua a sobreviver porque está ligado aos corpos que o acompanham. As personagens continuam a viver da mesma forma, não dando importância ao que está a acontecer nas ruas; o que parece estranho, tendo em conta que a escavadora vai deitar tudo abaixo, as pessoas terão de deixar o bairro de lata e ir viver para um bairro social. De facto, o som, que acompanha as sequências, comunica uma atmosfera de mudança, quase uma transformação indesejada e inoportuna com a qual ninguém se importa, mas que também ninguém pediu. $A$ rápida demolição do bairro, barulhenta e disforme, acompanha a lenta destruição dos habitantes das Fontainhas, na mente de quem tudo fica igual. "O trabalho incessante de demolição nunca deixa de ser auscultado, como se fosse o próprio pulsar do corpo daqueles adormecidos" (Spaziani citado em Cabo, 2009, p. 191). 
Pelo contrário, o vestuário está completamente permeado de uma imobilidade que reflete o estado de espírito de cada uma das personagens: quer seja uma camisola, um casaco ou uma t-shirt, a sua importância está relacionada com a completa imutabilidade de não querer modificar as coisas. De acordo com Pierre Bourdieu (1998), a sociedade não existe fora dos corpos, porque as conceções sociais vivem nos corpos, na maneira como o mundo é visto e na forma como se age e reage nele. O que Bourdieu chama habitus é a coerência e a constância usadas na forma dos corpos agirem, que se vai constituindo a partir de um conjunto de noções sobre o mundo. Estas noções derivam da experiência do que é possível e do que não é, a partir de uma determinada condição social, e agem a um nível subconsciente através da expressão de atitudes e práticas comportamentais. Cada indivíduo possui um habitus específico gerado por uma experiência-mundo, vivida a partir das posições ocupadas na sociedade, na família, no processo educativo e produtivo.

São estas as ligações que No Quarto da Vanda criam uma cumplicidade entre o corpo do ator e o seu revestimento, devido sobretudo à ligação entre o bairro e o seu significado, entre o realizador e a sua ideia universal do que é o cinema e, enfim, entre o espetador e as imagens que vê e que vão estimulando a sua disposição ética, ao sentir o quão próxima está aquela realidade.

Quando se fala da ligação entre corpos e bairro deve encarar-se como evidente a cultura por detrás destes elementos e a sua relativa perda, uma espécie de desenraizamento duplo. Desta forma, a ausência transforma-se em perda: "as suas casas eram os seus próprios corpos; agora estão como amputados" (Costa, 2008, p. 165). A perda da cultura, portanto, materializa-se num vestuário fortuito que não pretende mostrar mais nada senão a degradação e a inutilidade daqueles corpos. Esta perda também se materializa na ausência de sequências comunitárias, trocadas por planos lentos onde se consome o ritual de injeção da droga por homens que encarnam fantasmas sem passado nem futuro.

\section{CONCLUSÕES}

A análise individual de cada filme trouxe para a prática conceitos teóricos da Fashion Theory que conseguiram encaixar os filmes no natural encadeamento entre documentário e ficção. A proposta de o fazer do ponto de vista do vestuário visou explorar novas linhas narrativas, paralelas às que já existiam no argumento do filme, mas, ao mesmo tempo, tão importantes, quer na construção da personagem, quer na sua ambientação.

O já citado conceito de etnoficção foi útil para reunir características comuns de filmes diferentes: a vida longe da cidade, os grupos fechados, a comunidade e as suas regras, a luta constante entre a vontade individual e as regras impostas pela própria comunidade. Sem esquecer que, tratando-se de obras cinematográficas, a denominação de Etnofiç̧ão também se refletiria num estilo pessoal do próprio realizador e de sequências nunca claramente enquadradas na ficção ou no documentário.

Apesar de se estar longe dos conceitos fundamentais da moda propriamente dita e das bases de muitas das ideias da Fashion Theory, o ponto de partida foi a questão de que 
o vestuário de um filme etnográfico específico pudesse ter elementos interessantes, tanto a nível da ficção, como do documentário, mas também na sua própria especificidade de corpo revestido. Enquanto a associação entre traje e filme etnográfico ficou bem assente, sobretudo nas primeiras duas trilogias, onde as comunidades filmadas viviam longe da cidade e da sociedade moderna portuguesa em geral, a última trilogia foi a que trouxe mais novidades quer do ponto de vista da escolha da própria comunidade (o Bairro das Fontainhas), geograficamente perto da capital mas longe ou com uma relação quase inexistente com esta, quer do ponto de vista do estilo do realizador que, ao baralhar a fronteira entre a ficção e o documentário, impôs novas questões estilísticas, políticas e morais.

No que toca à presença de Pedro Costa, este foi aluno de António Reis na Escola de Teatro e Cinema no início dos anos 80 e, através das suas próprias declarações, sabe-se que foi graças à presença deste professor que conheceu o cinema português histórico, que até aquela altura era apenas um "conjunto de comédias dos anos 40 " (citado em Moutinho \& Lobo, 1997, p. 62), sendo que "a partir do momento em que vi Trás-os-Montes foi finalmente a oportunidade de começar a ter um passado no cinema português" (citado em Moutinho \& Lobo 1997, p. 65). A ligação entre os filmes da dupla e o cinema de Pedro Costa pode resumir-se no que este chama de "ligação entre planos" (citado em Moutinho \& Lobo 1997, p. 68), ou seja, aquele mínimo de intervenção fundamental para que, através do filme, o realizador se possa fundir com as personagens numa ordem que não é inventada, mas sim vista e reproduzida.

Talvez represente apenas outra forma de denominar aquilo que foi definido por António Reis ${ }^{6}$ como "Estética dos materiais". Tal é imediatamente notório a partir de Ossos, quando o olhar de Clotilde, que veste a bata de mulher da limpeza, cruza o olhar com a irmã Tina, e está ainda mais evidente em Vanda e as suas camisolas claras, como também está manifesto na personagem do Ventura de Juventude em Marcha que, ao não mudar de roupa durante o filme inteiro, vagueia de um sítio para outro, de um filho para outro, ou ainda melhor, de um plano para outro para transportar, como numa Via Cruz, o seu testemunho simultâneo de vergonha e orgulho. Podem classificar-se estas observações sob a denominação de "inamovibilidade do vestuário" (Cucinotta, 2015, p. 181), visando simbolizar uma inércia ou ausência de vontade por parte dos protagonistas em querer mudar as coisas, uma armadura que os separa dos eventos.

Em particular, torna-se apropriado utilizar a mesma expressão de António Reis, que começava também a entender esta tendência de totalidade da obra fílmica, chamando de estética dos materiais a uma espécie de aproximação visual entre o objeto filmado, o sujeito que filma e o próprio dispositivo cinematográfico. Através das trilogias analisadas, conseguiu traçar-se um percurso de emancipação do vestuário das suas funções básicas, de acordo com Bogatyrëv (1937), para uma crescente aproximação ao próprio meio cinematográfico. Ao abandonar a conceção do vestuário como mero revestimento,

\footnotetext{
${ }^{6}$ Afonso Cautela (em Moutinho \& Lobo, 1997, p. 235) relata que em Outubro de 1989, depois da projeção de Rosa de areia em Lisboa, no breve debate que se seguiu com os realizadores, o próprio António Reis "aludiu a uma das chaves do filme: optou-se por uma Estética dos materiais. Ali, de facto, joga-se com os materiais mais duros e puros, desde a rocha granítica e basáltica, à areia (sempre a areia), às palavras (como pedras), às cores, aos tecidos, aos ladrilhos, aos azulejos, à água, às palhas, ao vinho (do Porto!), ao mar das searas, ao oceano da terra, praticamente todas as texturas físicas que ali comparecem".
} 
o próprio adquire a posição de elemento dramático na comunicação do filme, juntamente com as outras escolhas estilísticas.

Frequentemente, coloca-se a questão sobre qual seria o ponto em comum entre cinema e revestimento do corpo, sobretudo se algum ponto de encontro haverá ou se se tratam de dois mundos paralelos que, ao cruzar-se, produzem um significado provisório. Encontraram-se algumas respostas interessantes no conceito de Sartorial Philosophy, expresso por Giuliana Bruno (2014), acerca da integração da moda no meio cinematográfico. Giuliana Bruno desenvolve uma perspetiva particular a partir da prática onde os dois mundos estão inscritos: se, para fazer um filme, devem pôr-se em prática os ofícios da montagem na edição e escolha das sequências fílmicas, também no caso da moda, cada peça de roupa resultará do conjunto de vários cortes que lhe concedem o seu aspeto final. A autora apelida o realizador de filmmaker-tailor, encontrando entre os dois mundos uma ligação indelével. Acerca da importância do corpo revestido ao nível fílmico, a autora apresenta uma atitude completamente concertada com o ponto de vista deste trabalho e que visa elevar o vestuário cinematográfico a um nível de significado superior ao que tradicionalmente tem sido considerado:

é um processo que põe em causa o que a moda geralmente representa na linguagem do cinema e o modo restritivo com que o termo é normalmente utilizado. Este exige uma revisão da opinião que estabelece que a moda em cinema é simplesmente guarda-roupa. Assim, a moda vai para além do figurino, tornando-se um objeto totalmente diferente na comunicação de significado. (Bruno, 2014, p. 39)

Não se trata de continuar a pensar o elemento fashion como componente separada dentro do filme, mas sim começar a reformular a sua presença como essencial à linguagem do filme, "contribuindo para a formação da sua textura estética" (Bruno, 2014, p. 54), num grau normalmente associado à representação, à cinematografia, à montagem e à cenografia.

Esta ideia de conectar o cinema com outros aspetos interessa-nos em particular, na relação entre o filme e a arte, entre as práticas visuais e a imaginação estética e traduz-se na urgência de instaurar uma relação entre os estudos fílmicos e outros produtos da modernidade, como por exemplo a Moda.

Concretamente, pensamos tratar-se uma ligação indissolúvel já expressada em vários ensaios acerca do vestuário, nas obras de cineastas internacionais como Peter Greenaway (Bruzzi, 1997), Wim Wenders, Wong Kar-wai (Bruno, 2002; 2014), Pierpaolo Pasolini (Colaiacomo, 2007), Luchino Visconti (Giannone \& Calefato, 2007) Luis Buñuel (Cousins, 2009), e é por este motivo que necessita de ser aprofundada, através de estudos críticos, a partir do contexto português para chegar a uma visão mais ampla da sua potencialidade enquanto construção tout-court da obra cinematográfica, a fim de entender o guarda-roupa de um filme, ou toda a direção de arte, como a criação de texturas sócio-históricas e conceder ao figurinista, ao cenógrafo e ao diretor artístico algumas responsabilidades a respeito do corpo do filme, da sua estética e da sua perceção no ecrã. " 


\section{REFERÊNCIAS BIBLIOGRÁFICAS}

Barthes, R. (1957-63/2009). Il sistema della moda. Torino: Einaudi.

Bogatyrëv, P. (1937/1986). Le funzioni del costume popolare nella Slovacchia morava. La ricerca folklorica: contributi allo studio della cultura dele classi popolari, 14, 93-120.

Bourdieu, P. (1998). Meditações pascalianas. Oeiras: ed. Celta.

Bruno, G. (2002). Atlas of emotion: Journeys in art, architecture, and film. Chicago: University of Chicago Press.

Bruno, G. (2014). Surface, matters of aesthetics, materiality, and media. Chicago: University of Chicago Press.

Bruzzi, S. (1997). Undressing cinema, clothing and identity in the movies. Nova lorque: Routledge.

Cabo, R. M. (Ed.) (2009). Cem mil cigarros. Os filmes do Pedro Costa. Lisboa: Orfeu Negro.

Calefato, P. (2002). Fashion theory. Retirado de http://www.culturalstudies.it/dizionario/pdf/fashion_theory.pdf

Calefato, P. (2007). Mass-moda, linguaggio e immaginario del corpo rivestito. Roma: Universale Melteni.

Colaiacomo, P. (2007). L'eleganza faziosa. Pasolini e l'abito maschile. Venezia: Marsilio.

Cook, P. (1996). Fashioning the nation. Costume and identity in British Cinema. Londres: BFI Publishing.

Costa P.; Neyrat C. \& Rector A. (2008). Um melro dourado um ramo de flores uma colher de prate. No Quarto da Vanda. Conversa com Pedro Costa. Lisboa: Midas Filmes e Orfeu Negro.

Cousins, J. (2008). Unstitching the 1950's film à costumes: hidden designers, hidden meanings. Tese de doutoramento, Universidade de Exeter, Exeter, Reino Unido. Retirado de https://ore.exeter.ac.uk/ repository/bitstream/handle/10036/42353/Cousins).pdf?seque

Cucinotta, C. (2015). O vestuário no cinema: percursos de análise em filmes portugueses de etnoficção. Tese de doutoramento, Universidade Nova de Lisboa, Lisboa, Portugal. Retirado de https://run.unl.pt/ handle/10362/16297

Ferreira, C. O. (2013). O cinema português - aproximações à sua história e indisciplinaridade. São Paulo: Alameda Casa Editorial.

Fidalgo, A. (1999). Da semiótica e seu objecto. Comunicação e Sociedade, 1, 19-40. Retirado de http:// revistacomsoc.pt/index.php/comsoc/article/view/1436/1366

Giannone, A. \& Calefato, P. (2007). Manuale di comunicazione, sociologia e cultura della moda (volume V, Performance). Roma: Meltemi Editore.

Greimas, A.J. (1985). Del senso 2. Milão: Bompiani.

Levinas, E. (1971). Totalità e infinito. Milão: Jaca Book.

Lurie, A. (2007). Il linguaggio dei vestiti. Roma: Armando Editore.

Marin, L. (1971). Utopiques: jeux d'espaces. Paris: Minuit

Moutinho, A. \& Lobo, M.G. (Eds.) (1997). António Reis e Margarida Cordeiro, a poesia da terra. Faro: Cineclube de Faro.

Mulvey, L. (1978). Piacere visivo e cinema narrativo. Nuova DWF, 8, 26-41. 
Onorati, M.G. (2000). Orlando: l'utopia di un corpo in transito. Lectora, 5-6.

Overhoff F. (2013). O cinema português - aproximações à sua história e indisciplinaridade. São Paulo: Alameda casa editorial.

Rascaroli, L. (2009). The personal camera: subjetive cinema and the essay film. Londres e Nova lorque: Wallflower.

Saussure, F., (2009). Corso di linguística generale. Roma-Bari: Laterza

Simmel, G. (1996). La moda. Milão: Oscar Mondadori.

Torres, A. R. (1991-1992). Estética da invisibilidade. A Grande Ilusão, 13-14, 124-125.

Verdone, M. (1986). Scena e costume nel cinema. Roma: Bulzoni editore.

Veblen, T. (1969). The theory of the leisure class. Nova Iorque: Modern Lybrary.

Watts, S. (1939). La technique du filme. Paris: Payot.

\section{FilmografiA}

Comissão de iniciativa da Nazareth (Produtora), Leitão de Barros, J. (realizador). (1927). Nazaré, Praia de Pescadores e Porto de Turismo. Portugal.

Sociedade Universal de Filmes LDA (Produtora), Leitão de Barros, J. (realizador). (1929). Maria do Mar. Portugal.

Tobis Portuguesa (Produtora), Leitão de Barros, J. (realizador). (1942). Ala arriba! Portugal.

Instituto Português de Cinema, Ministério da Comunicação Social (Produtores), Reis, A. \& Cordeiro, M. (realizadores). (1976). Trás-os-Montes. Portugal.

Branco, P. (Produtor), Reis, A. \& Cordeiro, M. (realizadores). (1982). Ana. Portugal

Secretaria de Estado da Cultura, RTP (Produtores), Reis, A. \& Cordeiro, M. (realizadores). (1989). Rosa de Areia. Portugal

Branco, P. (Produtor), Costa, P. (realizador). (1997). Ossos. Portugal

Contracosta Produções, Pandora Film (Produtores), Costa, P. (realizador). (2000). No Quarto da Vanda. Portugal

Villa-Lobos, F. (Produtor), Costa, P. (realizador). (2006). Juventude em Marcha. Portugal

\section{NOTA BIOGRÁFICA}

Caterina Cucinotta é doutorada em Ciências da Comunicação (Cinema e televisão) pela FCSH da UNL com uma tese sobre Vestuário no Cinema Português, com bolsa FCT. É investigadora do CECC (Centro de Estudos em Comunicação e Cultura). Tem escrito diversos artigos e capítulos de livros, especialmente sobre cinema português e suas ligações com a direção de arte. É membro da AIM - Associação de Investigadores da 
Imagem em Movimento e dos GT Historia do Cinema Português e Cinema em Português. Licenciou-se em Estudos Artísticos (especialização Teatro e Cinema) na Faculdade de Letras da Universidade de Palermo e obteve mestrado em Cinema e televisão pela Faculdade de Letras da Universidade de Bolonha. Trabalhou como jornalista freelance em Itália e em Portugal tem um percurso profissional na área do figurino de cinema.

E-mail: caterina.cucinotta@gmail.com

Rua da Escola Politécnica, 92, $3^{\circ}$ esquerdo, 1250-102, Lisboa, Portugal

* Submetido: 14-10-2016

* Aceite: 23-01-2017 